\title{
In vitro antileishmanial and cytotoxicity activities of essential oils from Haplophyllum tuberculatum A. Juss leaves, stems and aerial parts
}

Assia Hamdi ${ }^{1,4^{*}}$, Joanne Bero ${ }^{2}$, Claire Beaufay ${ }^{2}$, Guido Flamini ${ }^{3}$, Zohra Marzouk ${ }^{4}$, Yvan Vander Heyden $^{1 *}$ and Joelle Quetin-Leclercq ${ }^{2}$

\begin{abstract}
Background: Plants used for traditional medicine produce diverse and complex secondary metabolites exhibiting various medicinal properties. The medicinal plant Haplophyllum tuberculatum is used by native people against malaria and parasitic infections.

Methods: In this study and in order to contribute for the search of new natural drugs for leishmaniasis, the essential oils of $\mathrm{H}$. tuberculatum leaves, stems and aerial parts (leaves+stems) collected in two different periods, 2013 and 2015, and their components by GC/FID and GC/MS analyses were investigated. Those collected in 2013 were also re-analyzed two years later. The extracted oils were screened in vitro for anti-leishmanial activity on Leishmania mexicana mexicana (L.M.M.) promastigotes and cytotoxicity on the Chinese Hamster Ovary (CHO) cell line. Limonene (1.5 - 8\%), its isomers (R- (+)-limonene and S-(-)-limonene), linalool and octanol were also tested.

Results: Results showed that the chemical composition varied according to the year of collection. Though major compounds remain almost the same, qualitative and quantitative variations in the composition of the EOs can be observed between the two years of collection, with some minor compounds identified only in one type of samples. Variation in the composition were also observed in the re-analyzed volatile oils, showing stability concerns. The essential oils and $R-(+)$-limonene showed moderate anti-leishmanial activity. Their $I_{50}$ range from 6.48 to $50.28 \mathrm{\mu g} / \mathrm{ml}$. Cytotoxicity assays for theses volatile extracts, $R$ - (+)-limonene and S- (-)-limonene on $\mathrm{CHO}$ cells showed relatively potent cytotoxicity with a selectivity index $<10$. Their $\mathrm{CC}_{50}$ range from 27.79 to $82.56 \mu \mathrm{g} / \mathrm{ml}$.
\end{abstract}

Conclusions: The findings of the present study demonstrated that $\mathrm{H}$. tuberculatum might not be considered as a natural source for production of new anti-leishmanial agents without further analyzing its eventual in vivo toxicity as well as that of major pure compounds.

Keywords: Haplophyllum tuberculatum, Essential oils, Limonene, Anti-leishmanial, Cytotoxicity

\footnotetext{
*Correspondence: hamdiessia@gmail.com; Yvan.Vander.Heyden@vub.be ${ }^{1}$ Department of Analytical Chemistry, Applied Chemometrics and Molecular Modelling (FABI), Center for Pharmaceutical Research (CePhaR), Vrije Universiteit Brussel (VUB), Laarbeeklaan 103, 1090 Brussels, Belgium Full list of author information is available at the end of the article
} 


\section{Background}

Leishmaniasis are parasitic diseases. More than 20 Leishmania species have about 70 natural reservoir hosts and vectors including animals, such as dogs or rodents, and human bodies, and are transmitted by more than 90 sand fly species. These diseases are considered as a serious health concern which are occurring in Africa, Asia, Southern Europe and Latin America. Their prevalence rate was estimated from 900000 to 1.3 million new cases and from 20000 to 30000 deaths annually. The parasite may survive for decades in asymptomatic infected people and can also be transmitted directly from person to person. Many factors can increase leishmaniasis like malnutrition, migration, poor housing, a weak immune system, environmental and climatic changes such as deforestation and temperature variation and lack of financial resources [1-3]. In the absence of effective and sustainable vaccines, its control is still considered as a major public health problem [4]. The chemotherapy and the drugs based on pentavalent antimonials as sodium stibugluconate (Pentostam ${ }^{\circ}$ ) and meglumine antimoniate (Glucantime ${ }^{\oplus}$ ) are the current means of treatment [5]. Therefore, the required long-term treatment, toxicity, grave side-effects, pain, cost, drug resistance associated with treatment failures point out the crucial need for new agents in the treatment of leishmaniasis $[4,6]$.

Natural products traditionally used in folk medicine to treat several diseases are analyzed worldwide. In this regard, complex mixtures or purified compounds obtained from organic/aqueous extracts and essential oils of roots, stems, leaves, flowers, fruits and spices are various sources of diverse bioactive natural constituents [7-9]. The investigations showed that wild and cultivated plants exhibited various pharmacological activities such as antimicrobial, anticancer, anti-inflammatory, antiparasitic including anti-leishmanial ones [10]. Moreover, some plants essential oils and their main constituents displayed anti-leishmanial activities [6].

Haplophyllum tuberculatum A. Juss is a perennial herb, belonging to the rutaceae family, native of North Africa and other areas of the Middle East. The aerial part of this plant is used as laxative, to cure gastrointestinal affections, intermittent fevers, rheumatisms [11], malaria, gynecological disorders and renal disorders [12]. Moreover, reviews have reported $H$. tuberculatum as having nematicidal [13, 14], hepatoprotective [15], antiplasmodial [16, 17] and insecticidal activities [18]. Previous studies have also shown that $H$. tuberculatum is rich in volatile oils. Furthermore, these essential oils exhibited nematicidal [13], antimicrobial [19, 20], acetylcholinesterase inhibition and repellent activities [20].

The main aim of the present study is to analyze the volatile oils of different $H$. tuberculatum parts collected during two different seasons, to evaluate their antileishmanial effects against $L$. mexicana mexicana promastigote forms and their cytotoxic activities against $\mathrm{CHO}$ cells in an in vitro model. In order to relate the oils bioactivities to pure components ones, a major compound, limonene, and two minor ones, octanol and linalool, were tested in vitro. The other identified major compounds, cis-p-menth-2-en-1-ol, trans-p-menth-2en-1-ol, cis-piperitol are not commercially available.

\section{Methods}

\section{Plant material}

Plant material from the $H$. tuberculatum Forssk. (A. Juss) species was collected at the end of December 2012 and May 2015 from Beni Ghzayel, Medenine, an arid region in Tunisia $\left(33^{\circ} 21^{\prime} 17^{\prime \prime}\right.$ North $10^{\circ} 30^{\prime} 19^{\prime \prime}$ East). The herbarium specimens were authenticated with their morphological and anatomical features in the Botany Department, Faculty of Pharmacy Monastir Tunisia and Botany Department of Faculty of Sciences Sfax Tunisia, according to the flora of Tunisia [21] and a voucher specimen (H.t-01.03) was deposited in the Biological Laboratory of the Faculty of Pharmacy of Monastir. The leaves, stems and roots were cut into small pieces and weighed before extraction of volatile compounds.

\section{Extraction of essential oils}

About $100 \mathrm{~g}$ of fresh plant parts (leaves and/or stems or roots) was subjected to a $3 \mathrm{~h}$ hydrodistillation with $500 \mathrm{ml}$ of distilled water using a Clevenger-type apparatus (Clevenger, 1928). The leaves (L), stems (S), and leaves+stems (LS) essential oils (EO) obtained were separated from the distilled water and dried on anhydrous sodium sulphate. No oil was obtained from the roots part. The volatile extracts were stored in sealed glass vials at $4-5{ }^{\circ} \mathrm{C}$.

\section{Analytical GC-FID and GC-MS}

Three analyzes were done to identify the differential components in the three oils. Analyze 1 (Anlz1) referred to the oils extracted in 2013 and analyzed in 2014. The oils samples were re-analyzed in 2016, mentioned as Analyze 2 (Anlz2), in order to study the stability of the components. The third one (Anlz3) referred to samples extracted in 2015 and analyzed in 2016.

\section{GC conditions}

Gas chromatography (GC) analyses were carried out with an HP-5890 Series II instrument equipped with HP-WAX and HP-5 capillary columns $(30 \mathrm{~m} \times 0.25 \mathrm{~mm}$, $0.25 \mu \mathrm{m}$ film thickness), working with the following temperature program: $60{ }^{\circ} \mathrm{C}$ for $10 \mathrm{~min}$, ramp of $5{ }^{\circ} \mathrm{C} /$ min up to $220{ }^{\circ} \mathrm{C}$; injector and detector temperatures $250{ }^{\circ} \mathrm{C}$; carrier gas was helium $(2 \mathrm{~mL} / \mathrm{min})$; detector dual FID; split ratio 1:30; injection of $0.5 \mu \mathrm{L}$ (10\% hexane 
solution). Gas chromatography-electron impact mass spectroscopy analyses were performed with a Varian CP3800 gas chromatograph, equipped with a HP- 5 capillary column $(30 \mathrm{~m} \times 0.25 \mathrm{~mm}$; coating thickness $0.25 \mu \mathrm{m})$ and a Varian Saturn 2000 ion trap mass detector. Analytical conditions were as follows: injector and transfer line temperatures 220 and $240{ }^{\circ} \mathrm{C}$, respectively; oven temperature programmed from 60 to $240{ }^{\circ} \mathrm{C}$ at $3{ }^{\circ} \mathrm{C} /$ min; carrier gas helium at $1 \mathrm{ml} / \mathrm{min}$; injection of $0.2 \mu \mathrm{L}$ (10\% hexane solution); split ratio 1:30 [22-27].

\section{Identification and quantification of oils components}

The identification of the constituents was based on comparison of retention times with those of reference data or pure compounds based on their LRIs with the series of $n$ hydrocarbons. Moreover, identification of compounds also used gas chromatography-chemical ionization mass spectrometry, using methanol as the chemical ionizing gas [22-27] and computer matching against commercial (NIST 98 and ADAMS) and home-made library mass spectra (built up from pure substances and components of known oils and mass spectra literature data). The identified constituents were quantified by the normalization procedure using FID data.

\section{Standards compounds}

Octanol (for synthesis, Darmstadt, Germany, Merck), linalool (Buchs, Switzerland, Fluka), $R-(+)$-Limonen and $S$ - (-)-Limonen (96\%, Steinheim, Germany, SigmaAldrich) were provided by commercial suppliers and dissolved in dimethyl sulfoxide (DMSO) (Darmstadt, Germany, Merck). MTT, amphotericin B and campthotecin came from Sigma-Aldrich (Steinheim, Germany) and Alamar Blue were provided by Thermo Fisher Scientific (Aalst, Belgium).

\section{Anti-leishmanial activity}

The in vitro anti-leishmanial effects of essential oils from the leaves (LEO), stems (SEO) and the aerial parts of $H$. tuberculatum (LSEO) were investigated on Leishmania mexicana mexicana (L.m.m.) as described by [28]. The solutions were prepared in DMSO at $20 \mathrm{mg} / \mathrm{ml}$. Parasites in the logarithmic growth phase were seeded in 96well culture plates. Essential oils and compounds were tested in eight serial threefold dilutions $(0.05-100 \mu \mathrm{g} / \mathrm{ml}$, 2 wells/concentration). Amphotericin B was used as positive control with an initial concentration of $1 \mu \mathrm{g} / \mathrm{ml}$. The plate was kept at $28^{\circ} \mathrm{C}$ and after $72 \mathrm{~h}$ of incubation, Leishmania viability was calculated by quantification of Alamar Blue fluorescence $(10 \mu \mathrm{l}$ diluted two times in $\mathrm{PBS} /$ well incubated $4 \mathrm{~h}$ ), using an excitation wavelength of $530 \mathrm{~nm}$ and emission one of $590 \mathrm{~nm}$ on a SpectraMax M2e (Molecular Devices) spectrophotometer. Assays were performed in triplicate to calculate $\mathrm{IC}_{50}$.

\section{Cytotoxicity assay and selectivity index}

A tetrazolium salt colorimetric method has been used to determine survival of Chinese Hamster Ovary $(\mathrm{CHO})$ as described by Bero et al., 2009, with minor modifications [29]. The MTT (3-[4,5-dimethylthiazol-2-yl]-2,5 diphenyl tetrazolium bromide) assay is based on the conversion of MTT into formazan crystals by mitochondrial dehydrogenase in living cells. The solutions of essential oils were prepared in DMSO at $20 \mathrm{mg} / \mathrm{ml}$. The essential oils and compounds were firstly diluted in medium in eight serial threefold dilutions $(0.5-100 \mu \mathrm{g} / \mathrm{ml}, 3$ wells/ concentration) in 96-well microtiter plate. Secondly, 20 $\mu \mathrm{l}$ of diluted solutions were transferred to $180 \mu \mathrm{l}$ of 5 $10^{3}$ cells previously incubated during $24 \mathrm{~h}$. Finally, after $72 \mathrm{~h}$ of incubation, the medium was replaced by a $10 \%$ MTT solution (3 $\mathrm{mg} / \mathrm{ml}$ in PBS) in fresh medium and after $45 \mathrm{~min}$, the medium was replaced again by $100 \mu \mathrm{l}$ of DMSO added to solubilize formed formazan crystals. Absorbance was recorded at 570 and $620 \mathrm{~nm}$ on a SpectraMax M2e (Molecular Devices) spectrophotometer. Camptothecin was used as positive control at an initial concentration of $25 \mu \mathrm{g} / \mathrm{ml}$. Assays were performed in duplicate to calculate the $\mathrm{CC}_{50}$. The selectivity index (SI), expressed by the $\mathrm{CC}_{50} / \mathrm{IC}_{50}$ ratio [30], defines the balance between cytotoxicity and anti-leishmanial activity. If the SI value is higher than 10, treatment is considered as safe for the cells $(\mathrm{CHO})$ at the therapeutic concentration $[31,32]$.

\section{Statistical analysis}

The $\mathrm{IC}_{50}$ and $\mathrm{CC}_{50}$ of the bioassays were calculated by the least square ordinary fit method based on a sigmoidal curve. Statistical analysis was performed using Microsoft Excel as the average \pm SE for triplicates and duplicates of the anti-leishmanial and cytotoxicity assay, respectively. Data analysis was carried out by using SPSS statistical package version 16.0. Differences between the tests were analyzed by Duncan-test. $P<0.05$ was considered as statistically significant.

\section{Results}

\section{Chemical profiles of the oils}

The comparison of the data obtained for the same essential oil (EO) obtained from $H$. tuberculatum analyzed in 2014 and re-analyzed in 2016 showed qualitative and quantitative variations. Moreover, different chemical profiles were also observed between the EO extracted in 2013 and in 2015 (Table 1).

The main components present in the nine EO samples are $\alpha$-pinene, limonene, cis-p-menth-2-en-1-ol, trans-pmenth-2-en-1-ol, cis-piperitol, 1-octyl acetate, piperitone, isobornyl acetate with variation in their area percentages. Trans-piperitol is also a major compound in most oils but it was not detected in both LSEO analyzed 
Table 1 Chemical composition of the essential oil of Haplophyllum tuberculatum vegetal parts

\begin{tabular}{|c|c|c|c|c|c|c|c|c|c|c|}
\hline \multirow[b]{2}{*}{ Constituents } & \multirow[b]{2}{*}{ I.r.i. ${ }^{a}$} & \multicolumn{3}{|c|}{ EO 2013 (Anlz1) } & \multicolumn{3}{|c|}{ EO 2013 (Anlz2) } & \multicolumn{3}{|c|}{ EO 2015 (Anlz3) } \\
\hline & & LEO & SEO & LSEO & LEO & SEO & LSEO & LEO & SEO & LSEO \\
\hline ethyl isovalerate & 854 & - & - & - & - & - & - & - & 0.3 & - \\
\hline tricyclene & 928 & - & - & - & - & - & 0.1 & - & - & 0.2 \\
\hline a-thujene & 933 & - & - & - & - & - & - & - & - & 0.2 \\
\hline a-pinene & 941 & 2.9 & 4.6 & 3.9 & 1.4 & 3.4 & 4.6 & 2.1 & 4.6 & 7.2 \\
\hline camphene & 955 & 0.9 & 3.0 & 2.5 & 0.6 & 2.1 & 2.8 & 0.8 & 2.5 & 3.2 \\
\hline sabinene & 977 & 0.4 & - & 0.7 & 0.2 & 0.3 & 0.6 & 0.3 & 0.5 & 0.9 \\
\hline$\beta$-pinene & 981 & 1.1 & 3.4 & 2.9 & 0.7 & 2.5 & 3.0 & 0.9 & 3.5 & 3.9 \\
\hline myrcene & 993 & 3.3 & 0.8 & 1.3 & 0.7 & 0.4 & 0.9 & 1.0 & 2.1 & 2.6 \\
\hline octanal & 1002 & - & - & - & - & - & 0.3 & - & - & - \\
\hline a-phellandrene & 1006 & 0.4 & - & 0.7 & - & - & - & - & 2.8 & 3.8 \\
\hline a-terpinene & 1020 & - & - & 0.3 & - & - & - & - & - & - \\
\hline p-cymene & 1028 & 1.9 & 2.0 & 3.2 & 0.7 & - & 2.3 & 0.9 & 0.8 & 2.2 \\
\hline limonene & 1032 & 8.1 & 2.3 & 5.2 & 2.0 & 1.5 & 2.9 & 2.8 & 6.4 & 9.4 \\
\hline (E)- $\beta$-ocimene & 1052 & - & - & - & - & - & - & - & - & 0.2 \\
\hline (E)-2-octen-1-ol & 1071 & 0.4 & - & 0.7 & 0.6 & 0.9 & 0.7 & 0.6 & 0.6 & 0.4 \\
\hline 1-octanol & 1074 & 0.3 & 1.0 & 0.5 & - & 0.3 & - & - & - & - \\
\hline 1-nonen-3-ol & 1088 & 0.7 & 1.3 & - & 0.6 & 1.1 & 2.0 & 0.6 & 0.6 & 1.1 \\
\hline 2-nonanone & 1093 & - & - & 0.3 & - & - & 0.3 & - & - & - \\
\hline 2-methylbutyl 2-methylbutanoate & 1101 & - & - & - & - & - & - & - & 0.3 & - \\
\hline linalool & 1101 & 0.7 & - & 0.9 & 0.5 & - & 0.7 & 0.4 & - & 0.7 \\
\hline isopentyl 2-methylbutanoate & 1103 & 0.6 & - & 0.8 & 0.7 & 0.6 & 0.7 & 0.8 & - & - \\
\hline isopentyl isovalerate & 1104 & 0.4 & 0.6 & 0.6 & - & - & 0.4 & - & 2.0 & 1.0 \\
\hline pentyl isovalerate & 1106 & - & - & - & 0.4 & 0.5 & 0.7 & 0.4 & 1.5 & 0.7 \\
\hline cis-p-menth-2-en-1-ol & 1123 & 16.8 & 12.4 & 8.7 & 19.9 & 12.7 & 13.7 & 21.3 & 15.9 & 16.0 \\
\hline trans-p-menth-2-en-1-ol & 1142 & 16.2 & 11.2 & 8.2 & 17.8 & 11.2 & 12.2 & 18.8 & 11.8 & 12.6 \\
\hline pinocarvone & 1164 & - & - & 0.3 & - & - & 0.3 & - & - & - \\
\hline ethyl benzoate & 1172 & - & - & - & - & - & - & - & 0.5 & - \\
\hline 1-nonanol & 1173 & - & - & - & 0.2 & - & - & - & - & - \\
\hline 4-terpineol & 1179 & 0.4 & - & 0.8 & - & 0.7 & 0.6 & - & 0.5 & 0.4 \\
\hline cryptone & 1186 & - & - & 4.5 & 1.7 & 3.8 & 3.3 & 1.5 & 1.4 & 1.4 \\
\hline 1-dodecene & 1193 & - & - & - & - & 0.8 & - & - & - & - \\
\hline cis-piperitol & 1195 & 4.9 & 4.0 & 2.6 & 5.9 & 3.2 & 2.8 & 5.6 & 4.1 & 3.1 \\
\hline trans-piperitol & 1207 & 12.1 & 9.1 & 5.5 & 7.9 & 3.2 & - & 8.0 & 4.2 & - \\
\hline 1-octyl acetate & 1213 & 5.4 & 7.4 & 8.8 & 10.5 & 11.0 & 15.2 & 9.9 & 8.1 & 12.4 \\
\hline 3-methyl-3-hexen-1-yl butanoate & 1235 & 0.8 & - & - & - & - & - & - & - & - \\
\hline (Z)-3-hexenyl isovalerate & 1238 & - & - & - & 0.2 & - & - & - & - & - \\
\hline 2-nonyl acetate & 1243 & - & - & - & - & - & 1.0 & 0.7 & 0.3 & 0.5 \\
\hline hexyl isovalerate & 1243 & - & - & - & 0.6 & 0.6 & - & - & - & - \\
\hline cumin aldehyde & 1244 & - & 0.9 & - & 0.2 & 0.3 & 0.4 & - & - & - \\
\hline piperitone & 1254 & 6.7 & 8.5 & 9.1 & 8.1 & 8.0 & 9.6 & 7.5 & 6.8 & 5.2 \\
\hline 1-decanol & 1272 & - & - & - & 1.5 & - & - & 1.5 & - & - \\
\hline (Z)-3-tridecene & 1282 & - & 1.6 & 2.0 & - & - & - & - & - & - \\
\hline isobornyl acetate & 1287 & 2.0 & 13.8 & 7.8 & 3.0 & 15.0 & 9.8 & 2.8 & 9.8 & 7.3 \\
\hline
\end{tabular}


Table 1 Chemical composition of the essential oil of Haplophyllum tuberculatum vegetal parts (Continued)

\begin{tabular}{|c|c|c|c|c|c|c|c|c|c|c|}
\hline \multirow[b]{2}{*}{ Constituents } & \multirow[b]{2}{*}{ I.r.i. } & \multicolumn{3}{|c|}{ EO 2013 (Anlz1) } & \multicolumn{3}{|c|}{ EO 2013 (Anlz2) } & \multicolumn{3}{|c|}{ EO 2015 (Anlz3) } \\
\hline & & $\overline{\mathrm{LEO}}$ & SEO & $\overline{\text { LSEO }}$ & $\overline{\mathrm{LEO}}$ & SEO & $\overline{\text { LSEO }}$ & $\overline{\mathrm{LEO}}$ & SEO & LSEO \\
\hline 2-undecanone & 1293 & 0.4 & 1.0 & 0.9 & 0.4 & 0.6 & 0.5 & 0.4 & 0.5 & 0.2 \\
\hline 2-undecanol & 1304 & - & - & 0.6 & - & - & - & - & - & - \\
\hline neo-iso-isopulegol acetate & 1310 & - & - & 0.7 & - & - & - & - & - & - \\
\hline myrtenyl acetate & 1327 & - & - & 0.3 & - & 0.7 & - & - & - & - \\
\hline 3-oxo-p-menth-1-en-7-al & 1334 & - & - & 0.3 & - & - & - & - & - & - \\
\hline trans-piperitol acetate & 1343 & - & 0.9 & 1.0 & 0.6 & 0.9 & 0.9 & 0.6 & 0.6 & 0.4 \\
\hline neryl acetate & 1365 & 0.5 & 0.7 & 0.5 & 0.6 & 0.6 & 0.4 & 0.6 & 0.6 & 0.3 \\
\hline geranyl acetate & 1383 & - & - & - & 0.3 & 0.2 & - & - & - & - \\
\hline 1-decyl acetate & 1411 & - & - & - & 0.5 & 0.5 & 0.3 & 0.5 & 0.4 & - \\
\hline 1-decanol acetate & 1412 & 0.4 & - & 0.8 & - & - & - & - & - & - \\
\hline 1-octyl 2-methylbutanoate & 1434 & 1.6 & 1.1 & 1.5 & 1.6 & 0.7 & 1.0 & 1.7 & 0.8 & 0.7 \\
\hline 1-octyl isovalerate & 1440 & 1.2 & 1.9 & 1.4 & 1.1 & 0.8 & 0.8 & 1.0 & 1.0 & 0.6 \\
\hline germacrene D & 1482 & - & - & - & - & - & - & - & 0.7 & - \\
\hline ar-curcumene & 1483 & 0.6 & - & - & 0.7 & 0.3 & - & 0.6 & - & - \\
\hline 2-phenylethyl isovalerate & 1490 & - & - & - & 0.2 & - & - & - & - & - \\
\hline valencene & 1493 & 0.6 & 0.8 & 0.5 & 0.6 & 0.5 & 0.3 & 0.6 & 0.6 & - \\
\hline a-zingiberene & 1496 & - & - & - & - & - & - & - & 0.3 & - \\
\hline$\beta$-sesquiphellandrene & 1525 & 0.8 & - & - & 0.8 & - & - & 0.7 & 0.5 & - \\
\hline kessane & 1526 & - & - & - & - & 0.3 & - & - & - & - \\
\hline tetradecanal & 1612 & - & - & - & 0.4 & - & - & 0.3 & - & - \\
\hline a-cadinol & 1654 & - & - & - & 0.3 & 0.3 & - & - & 0.3 & - \\
\hline Y-dodecalactone & 1677 & - & - & - & 0.3 & 0.3 & - & - & - & - \\
\hline cis-14-nor-muurol-5-en-4-one & 1687 & - & - & - & 0.3 & - & - & - & - & - \\
\hline pentadecanal & 1716 & 0.9 & - & - & 1.9 & 0.3 & - & 1.5 & 0.3 & - \\
\hline Monoterpene hydrocarbons & & 19.0 & 16.1 & 20.7 & 6.3 & 10.2 & 17.2 & 8.8 & 23.2 & 33.8 \\
\hline Oxygenated monoterpenes & & 60.3 & 61.5 & 46.7 & 64.8 & 56.7 & 51.4 & 65.6 & 54.3 & 46.0 \\
\hline Sesquiterpene hydrocarbons & & 2.0 & 0.8 & 0.5 & 2.1 & 0.8 & 0.3 & 1.9 & 2.1 & 0.0 \\
\hline Oxygenated sesquiterpenes & & - & - & - & 0.6 & 0.6 & 0.0 & 0.0 & 0.3 & 0.0 \\
\hline Non-terpene derivatives & & 13.1 & 15.9 & 23.4 & 23.4 & 22.8 & 27.2 & 21.4 & 18.6 & 19.0 \\
\hline Total identified & & 94.4 & 94.3 & 91.3 & 97.2 & 91.1 & 96.1 & 97.7 & 98.5 & 98.8 \\
\hline
\end{tabular}

a Linear retention indices (DB-5 column)

Analyze 1 (Anlz1): volatile oils extracted in 2013 and analyzed in 2014

Analyze 2 (Anlz2): volatile oils extracted in 2013 and re-analyzed in 2016

Analyze 3 (Anlz3): volatile oils extracted in 2015 and analyzed in 2016

The number of extraction repetitions: all EOs samples are extracted once

in 2016. The minor compounds found in all EOs are 2undecanone, neryl acetate, 1-octyl 2-methylbutanoate, 1octyl isovalerate. The amounts of myrcene and camphene vary between 0.8 and $3.3 \%$ and 0.6 and $3.2 \%$ respectively.

By comparing the EO analyzed in 2014 and re-analyzed in 2016, new compounds were detected in that of 2016 as tricyclene, octanal, pentyl isovalerate, 1-nonanol, 1dodecene, (Z)-3-hexenyl isovalerate, 2-nonyl acetate, hexyl isovalerate, 1-decanol, geranyl acetate, 1-decyl acetate, 2phenylisovalerate, kessane, tetradecanal, $\alpha$-cadinol, $\gamma$ - dodecalactone, cis-14-nor-muurol-5-en-4-one but as minor compounds. However, $\alpha$-phellandrene, $\alpha$-terpinene, 3-methyl-3-hexen-1-yl butanoate, (Z)-3-tridecene, 2undecanol, neo-iso-isopulegol acetate, 3-oxo- $p$-menth-1en-7-al, 1-decanol acetate disappeared in the Anlz2, but these compounds were minor in Anlz1 (Table 1).

The non-terpene derivatives increased in all oils. They were ranging from $13.1 \%$ to $23.4 \%$, from $15.9 \%$ to 22.8 and from $23.4 \%$ to $27.2 \%$ for LEO, SEO and LSEO respectively. The oxygenated monoterpenes increased from $60 \%$ to $64.8 \%$; from $46.7 \%$ to $51.5 \%$ for LEO and 
LSEO respectively and decreased from $61.5 \%$ to $56.7 \%$ for SEO, while the monoterpene hydrocarbons decreased in the EOs of all parts, from $19.0 \%$ to $6.3 \%$; from 16.1 to $10.2 \%$ and from 20.7 to $17.2 \%$ for LEO, SEO and LSEO respectively.

On the other hand, new compounds were detected in the Anlz3 compared to Anlz1 as ethyl isovalerate, $\alpha$ thujene, (E)- $\beta$-ocimene, 2-methylbutyl 2-methylbutanoate, ethyl benzoate, 1-decanol, 1-decyl acetate, germacrene D, $\alpha$-zingiberene, tetradecanal, $\alpha$-cadinol but some of them were present in Anlz 2. Moreover, some compounds were not detected in the Anlz3 as $\alpha$-terpinene, 1-octanol, 2nonanone, pinocarvone, 3-methyl-3-hexen-1-yl butanoate, cumin aldehyde, (Z)-3-tridecene, 2-undecanol, neo-iso-isopulegol acetate, myrtenyl acetate, 3-oxo- $p$-menth-1-en-7al, 1-decanol acetate. When comparing Anlz 1 and Anlz 3, monoterpene hydrocarbons decreased from $19.0 \%$ to $8.8 \%$ for LEO; increased from 16.1 to $23.2 \%$ and from 20.7 to $33.8 \%$ for SEO and LSEO, respectively. The oxygenated monoterpenes increased from $60.3 \%$ to $65.6 \%$ for LEO, decreased from $61.5 \%$ to $54.3 \%$ and from $46.7 \%$ to $46.0 \%$ for SEO and LSEO respectively. The non-terpene derivatives increased from $13.1 \%$ to $21.4 \%$ from $15.9 \%$ to $18.6 \%$ for LES and SEO respectively and decreased from $23.4 \%$ to $19.0 \%$ in LSEO.

Dissimilarity was noted in the Anlz2 and Anlz3. Eight compounds were detected in the Anlz3 but not in Anlz2: ethyl isovalerate, $\alpha$-phellandrene, $\alpha$-thujene, $(E)$ - $\beta$-ocimene, 2-methylbutyl 2-methylbutanoate, ethyl benzoate, germacrene D, $\alpha$-zingiberene. However, octanal, $\alpha$-terpinene, 1octanol, 2-nonanone, pinocarvone, 1-nonanol, 1-dodecene, 3-methyl-3-hexen-1-yl butanoate, (Z)-3-hexenyl isovalerate, hexyl isovalerate, cumin aldehyde, (Z)-3-tridecene, 2undecanol, neo-iso-isopulegol acetate, myrtenyl acetate, 3oxo- $p$-menth-1-en-7-al, geranyl acetate, 1-decanol acetate, 2 -phenylethyl isovalerate, kessane, $\gamma$-dodecalactone, cis-14nor-muurol-5-en-4-one were not identified in the Anlz3. The monoterpene hydrocarbons increased in the EO of all parts, from $6.3 \%$ to $8.8 \%$; from 10.2 to $23.2 \%$ and from 17.2 to $33.8 \%$ for LEO, SEO and LSEO respectively. Moreover, the oxygenated monoterpenes increased from $64.8 \%$ to $65.6 \%$ for LEO, decreased from $56.7 \%$ to $54.3 \%$ and from $51.4 \%$ to $46.0 \%$ for SEO and LSEO respectively. However, the non-terpene derivatives decreased in all the oils. They were ranging from $23.4 \%$ to $21.4 \%$, from $22.8 \%$ to 18.6 and from $27.2 \%$ to $19.0 \%$ for for LEO, SEO and LSEO respectively. In general, $H$. tuberculatum $\mathrm{EO}$ were characterized by high percentages of oxygenated monoterpenes followed by hydrocarbon monoterpenes and non-terpene derivatives.

\section{Anti-leishmanial activity}

In this study, promastigotes of L.m.m. were incubated in the presence of various concentrations of essential oils and pure compounds. The cell viability was determined after $72 \mathrm{~h}$ using Alamar Blue assay. This is the first time that the anti-leishmanial activity of $H$. tuberculanum essential oils is shown with $\mathrm{IC}_{50}$ range from 6.48 to $>100$ $\mu \mathrm{g} / \mathrm{ml}$ and dose-dependent responses $(P \leq 0.05$ : Table 2$)$.

The LEO 2013 and SEO 2013 had a similar effect while LSEO 2013 was the most active on L.m.m. ( $\mathrm{IC}_{50}$ values: $16.69,16.00$ and $6.48 \mu \mathrm{g} / \mathrm{ml}$, respectively). The LEO, SEO and LSEO, samples collected and extracted in 2015, showed $\mathrm{IC}_{50}$ values of $19.44,50.28$ and $61.79 \mu \mathrm{g} /$ $\mathrm{ml}$, respectively with a significant decrease in activity for SEO and LSEO 2015. Moreover, there is no significant difference between the $\mathrm{IC}_{50}$ of LEO 2013, SEO 2013 and that of LEO $2015(p<0.05)$.

\section{Cytotoxicity and selectivity index}

Cytotoxic effects of $H$. tuberculatum oils were determined in $\mathrm{CHO}$ cells using MTT assay. The obtained finding indicated significant cytotoxicity of the essential oils and the tested pure compounds on $\mathrm{CHO}$ cells with $\mathrm{CC}_{50}$ range from 27.79 to $>100 \mu \mathrm{g} / \mathrm{ml}$ (Table 2).

$R$-(+)-limonene $\left(\mathrm{CC}_{50}=29.65 \mu \mathrm{g} / \mathrm{ml}\right)$ and LSEO 2013 $\left(\mathrm{CC}_{50}=27.79 \mu \mathrm{g} / \mathrm{ml}\right)$ had the highest cytotoxic effect on cells compared to the other samples. LEO 2013, LEO 2015, SEO 2015, LSEO 2015 and $S$-(-)-limonene exhibited a similar low cytotoxic effect $(P>0.05)$.

The selectivity index (SI) for LEO extracted in 2013 and 2015 and LSEO 2013 were 4.86, 4.15 and 4.29, respectively, showing that they were less toxic on $\mathrm{CHO}$ cells than Leishmania parasites. However, in all cases, they are lower than 10 , the minimum value defined for the selection of an anti-parasitic hit [31,32]. Thus these oils could perhaps be used safely at therapeutic concentration in short term treatments but $R-(+)$-limonene $(\mathrm{SI}=1.79)$ cannot be considered as a drug candidate for the development of anti-leishmanial agents.

\section{Discussion \\ Chemical profiles of the oils}

Literature review showed variation between chemical compositions, depending on the location and stages of development of $H$. tuberculatum. Reports from Oman [19], Iran [33] and the United Arab Emirates [34] showed a difference between the major compounds. The comparison of the chemical composition from the different parts of our $H$. tuberculatum with that of $H$. tuberculatum from Oman showed that the main compounds varied [19]. Indeed, the main compounds of $H$. tuberculatum from Oman were beta-phellandrene (23.3\%), limonene (12.6\%), (Z)-beta-ocimene (12.3\%), beta-caryophyllene (11.6\%), myrcene (11.3\%), and alpha-phellandrene (10.9\%) [19]. Another study showed that the main constituents of the EO from the aerial parts were limonene (27.3\%) and $\alpha$ pinene (21.9\%) [33]. Furthermore, the composition of the EO varied also according to the collecting season. 
Table 2 Anti-leishmanial $\left(\mathrm{C}_{50} \pm \mathrm{SD}\right)$ and cytotoxic activity $\left(\mathrm{CC}_{50} \pm \mathrm{SD}\right)$ of essentials oils, some of their components and the positive controls

\begin{tabular}{|c|c|c|c|}
\hline & $\begin{array}{l}\text { Anti-leishmanial activity - promastigotes } \\
\text { (L. mexicana mexicana) }\end{array}$ & Cytotoxicity - $\mathrm{CHO}$ & Selectivity index \\
\hline Samples & $\mathrm{IC}_{50}(\mu \mathrm{g} / \mathrm{ml}) \pm \mathrm{SD}$ & $\mathrm{CC}_{50}(\mu \mathrm{g} / \mathrm{ml}) \pm \mathrm{SD}$ & $\mathrm{CHO} / \mathrm{Lmm}$ \\
\hline LEO 2013 & $16.69 \pm 0.35^{c}$ & $81.20 \pm 1.59^{d}$ & 4.86 \\
\hline SEO 2013 & $16.00 \pm 0.56^{c}$ & $49.64 \pm 8.56^{c}$ & 3.10 \\
\hline LSEO 2013 & $6.48 \pm 0.44^{b}$ & $27.79 \pm 3.73^{b}$ & 4.29 \\
\hline LEO 2015 & $19.44 \pm 1.00^{c}$ & $80.65 \pm 1.60^{d}$ & 4.15 \\
\hline SEO 2015 & $50.28 \pm 2.13^{d}$ & $82.56 \pm 5.51^{d}$ & 1.64 \\
\hline LSEO 2015 & $61.79 \pm 5.05^{\mathrm{e}}$ & $79.06 \pm 0.80^{d}$ & 1.28 \\
\hline$R$ - (+)-limonene & $16.59 \pm 0.35^{c}$ & $29.65 \pm 0.78^{b}$ & 1.79 \\
\hline S- (-)-limonene & $>100$ & $75.89 \pm 0.88^{d}$ & - \\
\hline 1-octanol & $>100$ & $>100$ & - \\
\hline linalool & $>100$ & $>100$ & - \\
\hline Amphotericin B & $0.10 \pm 0.01^{\mathrm{a}}$ & nd & - \\
\hline Camptothecin & nd & $0.74 \pm 0.09^{a}$ & - \\
\hline
\end{tabular}

The letters (a-e) indicate significant differences between the samples according to the Duncan Test $(p<0.05)$

The analysis of the aerial parts of $H$. tuberculatum collected in May 1997 and 2001 from the United Arab Emirates showed that the major compounds were $\alpha$ phellandrene (10.7-32.9\%), $\beta$-caryophyllene (6.3-12.8\%), $\beta$-pinene $(7.6-8.0 \%)$, limonene $(4.0-9.6 \%)$ and $\delta$-3carene (5.5-6.0\%). However, the oil distilled from plants collected in April (1998) had as major components linalool (15.0\%), linalyl acetate (10.6\%), $\beta$-caryophyllene (9.7\%) and $\alpha$-terpineol (6.7\%) [34].

Conversion and degradation reactions can be involved in these changes because of the metabolic relation between terpenoid biosynthesis and the effect of different factors such as temperature or light. This was already observed i.e. for laurel and fennel $[35,36]$. The differences in composition observed between our results and those of the previous works might be related to the analyzed plant part (leaves, stems, leaves+stems and aerial part), the geographic origin of the populations, the ecological conditions in which they grow and also chemical instability or transformation, but may also suggest the existence of a new chemotype.

\section{Anti-leishmanial activity}

This variability in anti-leishmanial activity may be explained by the qualitative and quantitative differences in chemical compositions of each essential oils. Indeed, literature showed that the chemical composition of essential oils and so their biological activities may be affected by the growing seasons. Some factors may be considered as responsible for these variations as temperature, rainfall and humidity which can affect plant metabolism and lead to composition differences [37].
Among the pure compounds, $R-(+)$-limonene was the most active one $\left(\mathrm{IC}_{50}=16.59 \mu \mathrm{g} / \mathrm{ml}\right)$ compared to inactive $S$-(-)-limonene, linalool and 1-octanol ( $\mathrm{IC}_{50}$ $>100 \mu \mathrm{g} / \mathrm{ml})$. It can explain a part of the anti-leishmanial activity but other active compounds still remain to be identified. Kpadonou Kpoviessi et al., 2014 also, showed that $R-(+)$-limonene had an antitrypanosomal effect with $\mathrm{IC}_{50}=4.24 \pm 2.27 \mu \mathrm{g} / \mathrm{mL}$ on Trypanosoma brucei brucei bloodstream forms [38]. As well, linalool was shown to have a strong inhibitory activity on L. amazonensis promastigotes and amastigotes with $\mathrm{LD}_{50}$ of $15.5 \mathrm{ng} / \mathrm{ml}$ and $4.3 \mathrm{ng} / \mathrm{ml}$, respectively [39].

Some of the compounds present in our volatile oils were already tested for their anti-parasitic activities. Thus, the $\mathrm{IC}_{50}$ of alpha-pinene $(55.3 \mu \mathrm{g} / \mathrm{mL} ; 4.1 \mu \mathrm{g} / \mathrm{mL})$, sabinene $(126.6 \mu \mathrm{g} / \mathrm{mL} ; 17.7 \mu \mathrm{g} / \mathrm{mL}), \beta$-pinene $(200.1 \mu \mathrm{g} /$ $\mathrm{mL} ; 54.8 \mu \mathrm{g} / \mathrm{mL}), \alpha$-phellandrene $(32.8 \mu \mathrm{g} / \mathrm{mL} ; 9.2 \mu \mathrm{g} / \mathrm{mL})$, 4-terpineol $(335.9 \mu \mathrm{g} / \mathrm{mL} ; 0.02 \mu \mathrm{g} / \mathrm{mL})$ were reported against promastigotes of $L$. major and the bloodstream forms of T. brucei (TC 221), respectively [40].

\section{Cytotoxicity and selectivity index}

Both isomers, $R-(+)$-limonene and $S$-(-)-limonene, can account for at least a part of the cytotoxic activity of the EOs. Thus, once again, the cytotoxic variabilities of the samples can be related to the studied plant part and the season of collection [37].

The cytotoxicity of $R$-(+)-limonene was a little higher than that described by Kpoviessi et al. (2014) but the difference (factor less than 2) may be explained by the general biological variability of cells in culture. Moreover, our study showed that 1-octanol and linalool $\left(\mathrm{CC}_{50}>100 \mu \mathrm{g} /\right.$ $\mathrm{ml}$ ) had no cytotoxicity on $\mathrm{CHO}$ cells. 
Some studies analyzed the specific cellular targets of single components on the cells. Recent research demonstrated that linalool was not cytotoxic on some cell types $\left(\mathrm{CC}_{50}>200 \mu \mathrm{g} / \mathrm{ml}\right)$ : Vero, Macrophages, A-549, HeLa, HT-29 cells Saulo [41] but can inhibit mitochondrial complexes I and II, increase reactive oxygen species and inhibit the HepG2 cells viability $\left(\mathrm{IC}_{50}=0.4 \mu \mathrm{M}\right)$ [42].

Apoptosis induction was observed for linalool on MCF7 WT cells $\left(\mathrm{IC}_{50}=0.62-0.79 \mu \mathrm{M}\right)[43]$ and on HL-60 $\left(\mathrm{IC}_{50}=49.53-127.14 \mu \mathrm{M}\right)$ [44], limonene on $\mathrm{K} 562$ $\left(\mathrm{IC}_{50}=\mathrm{ND}\right)$ [45], HT-29 $5\left(\mathrm{IC}_{50}>200 \mu \mathrm{g} / \mathrm{mL}\right)$ [46], alphapinene on $\mathrm{U} 937\left(\mathrm{IC}_{50}=\mathrm{ND}\right)$ [47], pancreatic, mammary, and prostatic tumors $\left(\mathrm{IC}_{50}=\mathrm{ND}\right)[48]$.

No cytotoxicity was observed for 1-octanol. Published data on the cytotoxicity of other $H$. tuberculatum components showed a great activity variability according to used cell types. Alpha-pinene was cytotoxic on K562 $\left(\mathrm{IC}_{50}=117.3 \mu \mathrm{M}\right)$ [49], HL-60 $\left(\mathrm{IC}_{50}=2.5 \mu \mathrm{g} / \mathrm{mL}\right)$ [40], A$549\left(\mathrm{IC}_{50}=183.2 \mu \mathrm{g} / \mathrm{mL}\right), \mathrm{HeLa}\left(\mathrm{IC}_{50}=172.7 \mu \mathrm{g} / \mathrm{mL}\right)$, but not on Vero, macrophages and HT-29 [41]. Sabinene $\left(\mathrm{IC}_{50}=23.6 \mu \mathrm{g} / \mathrm{mL}\right)$ and $\alpha$-phellandrene $\left(\mathrm{IC}_{50}=26.9 \mu \mathrm{g} /\right.$ $\mathrm{mL}$ ) were cytotoxic on HL-60, respectively [40]. The cytotoxicity of $\beta$-pinene was studied on CHO and WI38 $\left(\mathrm{IC}_{50}>50 \mu \mathrm{g} / \mathrm{mL}\right), \mathrm{HL}-60 \quad\left(\mathrm{IC}_{50}=29.6 \mu \mathrm{g} / \mathrm{mL}\right) \quad[40]$ and $\mathrm{K} 562\left(\mathrm{IC}_{50}=157.4 \mu \mathrm{M}\right)[49]$. Myrcene showed an activity on HepG2 $\left(\mathrm{IC}_{50}=9.23 \mu \mathrm{g} / \mathrm{ml}\right), \mathrm{B} 16-\mathrm{F} 12 \quad\left(\mathrm{IC}_{50}=12.27 \mu \mathrm{g} /\right.$ ml) [50], but not on Vera, macrophages, A 549, HT 29, $\mathrm{CHO}, \mathrm{PBMC}$ and WI38 cells $[41,51]$. $p$-Cymene exhibited a cytotoxic effect on B16-F12 $\left(\mathrm{IC}_{50}=20.06 \mu \mathrm{g} / \mathrm{mL}\right)$ but not on CHO, WI38 [51], HepG2 and on PBMC [50]. 4-Terpineol demonstrated an effect on HL-60 $\left(\mathrm{IC}_{50}=20.5 \mu \mathrm{g} / \mathrm{mL}\right) \quad[40]$ and on $\mathrm{AE} 17 \quad\left(\mathrm{IC}_{50}=0.02 \%\right.$; $0.01 \%), \mathrm{B} 16\left(\mathrm{IC}_{50}=0.05 \% ; 0.04 \%\right), \mathrm{HF} 32\left(\mathrm{IC}_{50}=0.1 \%\right.$; $0.1 \%$ ) after 24 and $48 \mathrm{~h}$, respectively [52].

Literature data indicate that $H$. tuberculatum organic extracts possess a high cytotoxicity [53, 54]. This cytotoxicity may be explained by the cytotoxic lignans already identified in this species [55]. However, it cannot explain cytotoxicity of its essential oils which should not contain these lignans.

Previous studies showed that promastigotes cultures are a validated model for primary screening. Promastigotes are known to be less sensitive than amastigotes to drugs and allow a restricted selection of the most active samples before performing an intracellular amastigotes test [56]. However, as shown by the present results, the EOs have high cytotoxicity and the selectivity indices are not encouraging enough to proceed to the intracellular tests.

\section{Conclusions}

Results showed that the chemical composition varied according to the year of collection, but that stabilities issues may also modify the composition $\mathrm{n}$ along the time, as shown by the variation observed in the re-analyzed volatile oils.

Our results showed that the chemical composition of the essential oils of different parts (leaves, stems and leaves+stems) from $H$. tuberculatum varied according the period of collection. The re-analyzed volatile oils indicated that stabilities issues may also modify their composition along the time. The tested essential oils and one of their major component $(R-(+)$-limonene) were biologically active against $L$. mexicana mexicana coupled to a cytotoxic effect on $\mathrm{CHO}$ in vitro.

However, as limonene is only present at concentration $<10 \%$, other compounds and/or synergistic effects remain to be analyzed to explain the observed activities. Thus, the biological activities of the identified major compounds, cis-p-menth-2-en-1-ol, trans-p-menth-2en-1-ol, cis-piperitol should be evaluated.

The results obtained in this study confirm the importance of chemical and biological investigations of essential oils but also toxicity risks. So in vitro studies are needed to assess the potential of these oils as antileishmanial agents and analyze deeper toxicity risks.

To our knowledge this is the first report of the antileishmanial and cytotoxic activity of the essential oils of H. tuberculatum.

\section{Abbreviations}

$\mathrm{CC}_{50}$ : Cytotoxic concentration of extract decreasing by $50 \%$ the number of viable cells; EO: Essential oil; $\mid C_{50}$ : Sample concentration inhibiting $50 \%$ of viable parasites; LEO/SEO/LSEO: Leaves/stems/leaves+stems essential oils; L.m.m: Leishmania mexicana mexicana; MTT: 3-[4,5-dimethylthiazol-2-yl]-2,5 diphenyl tetrazolium bromide

\section{Acknowledgments}

We are grateful to Madame Maude Bourlet for her assistance to carry out the bioassays.

\section{Funding}

This work is partly supported by the Belgian Fund of Scientific Research (FNRS) T.0190.13.

\section{Availability of data and materials}

The plant materials and methods used were available upon request. All data obtained have been included into the manuscript.

\section{Author's contributions}

$\mathrm{AH}$ collected plant material, extracted essential oils, tested the biological activities of essential oils and analyzed data; JB developed the methods; CB controlled experiments; GF identified chemical composition of essential oils; ZM identified the plant; $\mathrm{YVH}$ contributed to manuscript preparation and JQL supervised the study and edited the manuscript. All authors have read and approved the manuscript.

Ethics approval and consent to participate Not applicable.

Consent for publication

Not applicable.

Competing of interests

The authors declare no commercial, financial or any other conflict of interest. 


\section{Publisher's Note}

Springer Nature remains neutral with regard to jurisdictional claims in published maps and institutional affiliations.

\section{Author details}

'Department of Analytical Chemistry, Applied Chemometrics and Molecular Modelling (FABI), Center for Pharmaceutical Research (CePhaR), Vrije Universiteit Brussel (VUB), Laarbeeklaan 103, 1090 Brussels, Belgium. ${ }^{2}$ Pharmacognosy Research Group (GNOS), Louvain Drug Research Institute (LDRI), Université catholique de Louvain (UCL), B1.72.03 Av. E. Mounier 72, B-1200 Bruxelles, Belgium. ${ }^{3}$ Dipartimento di Scienze Farmaceutiche, Sede Chimica Bioorganica e Biofarmacia, Università di Pisa, Via Bonanno 33, 56126 Pisa, Italy. ${ }^{4}$ Laboratoire de Développement Chimique Galénique et Pharmacologique des Médicaments. Faculté de Pharmacie, Université de Monastir, 5000 Monastir, Tunisia.

\section{Received: 19 May 2017 Accepted: 7 February 2018}

\section{Published online: 14 February 2018}

\section{References}

1. Organization World Health. WHO report on global surveillance of epidemicprone infectious diseases. 2000

2. Organization World Health. Weekly Epidemiological Record. 2016;91:441-60.

3. Organization World Health. Fact sheet no. fs375; 2013; Updated September 2016.

4. Duthie MS, Raman VS, Piazza FM, Reed SG. The development and clinical evaluation of second-generation leishmaniasis vaccines. Vaccine. 2012;30: 134-41.

5. Rodrigues KAF, Amorim LV, Dias CN, Moraes DFC, Carneiro SMP, Carvalho FAA. Syzygium cumini (L.) Skeels essential oil and its major constituent apinene exhibit anti-Leishmania activity through immunomodulation in vitro. J Ethnopharmacol. 2015;160:32-40.

6. Essid R, Rahali FZ, Msaada K, Sghair I, Hammami M, Bouratbine A, Aoun K, Limam F. Antileishmanial and cytotoxic potential of essential oils from medicinal plants in Northern Tunisia. Ind Crops Prod. 2015;77:795-802

7. Askun T, Tumen G, Satil F, Ates M. In vitro activity of methanol extracts of plants used as spices against Mycobacterium tuberculosis and other bacteria. Food Chem. 2009;116:289-94.

8. Martin-Puzon JJR, Rivera WL. Free-radical scavenging activity and bioactive secondary metabolites from various extracts of Glinus oppositifolius (L.) Aug. DC. (Molluginaceae) roots, stems and leaves. Asian Pac J Trop Dis. 2015;5: $711-5$.

9. Rana S, Kumar S, Rana A, Sharma V, Katoch P, Padwad Y, Bhushan S. Phenolic constituents from apple tree leaves and their in vitro biological activity. Ind Crops Prod. 2016;90:118-25.

10. Tamilselvan N, Thirumalai T, Shyamala P, David E. A review on some poisonous plants and their medicinal values. J Acute Dis. 2014;3:85-9.

11. Boulos L: Medicinal Plants of North Africa. Medicinal plants of North Africa 1983.

12. Mohamed AH, Ali MB, Bashir AK, Salih AM. Influence of Haplophyllum tuberculatum on the Cardiovascular System. Int J Pharmacogn. 1996;34:213-7.

13. Onifade AK, Fatope MO, Deadman ML, Al-Kindy SMZ. Nematicidal activity of Haplophyllum tuberculatum and Plectranthus cylindraceus oils against Meloidogyne javanica. Biochem Syst Ecol. 2008:36:679-83.

14. Kallel $\mathrm{S}$, Ben Ouadday $M Z, Z$ G G. Évaluation de l'activité nématotoxique d'Haplophyllum tuberculatum sur meloidogyne javanica. Nematol Mediterr. 2009;37:45-52

15. Ali BH, Bashir AK, Rasheed RA. Effect of the traditional medicinal plants Rhazya stricta, Balanitis aegyptiaca and Haplophylum tuberculatum on paracetamol-induced hepatotoxicity in mice. Phytother Res PTR. 2001;15: 598-603.

16. El-Tahir A, Satti GM, Khalid SA. Antiplasmodial activity of selected sudanese medicinal plants with emphasis on Acacia nilotica. Phytother Res PTR. 1999; 13:474-8.

17. Khalid SA, Farouk A, Geary TG, Jensen JB. Potential antimalarial candidates from African plants: an in vitro approach using Plasmodium falciparum. J of ethnopharmacol. 1986;15:201-9.

18. Mohsen ZH, Jaffer HJ, Alsaadi M, Ali ZS. Insecticidal effects of Haplophyllum tuberculatum against Culex quinquefasciatus. Int J Crude Drug Res. 1989;27: $17-21$.
19. Al-Burtamani SK, Fatope MO, Marwah RG, Onifade AK, Al-Saidi SH. Chemical composition, antibacterial and antifungal activities of the essential oil of Haplophyllum tuberculatum from Oman. J of ethnopharmacol. 2005;96: 107-12.

20. Al-Rehaily AJ, Alqasoumi SI, Yusufoglu HS, Al-Yahya MA, Demirci B, Tabanca $\mathrm{N}$, Wedge DE, Demirci F, Bernier UR, Becnel JJ. Chemical Composition and biological activity of Haplophyllum tuberculatum Juss. essential oil. J Essent Oil Res. 2014;17:452-9.

21. Pottier-Alapetite G. Flore de la Tunisie : Angiospermes - Dicotylédones. Ministère de l'Enseignement supérieur et de la Recherche scientifique et ministère de l'Agriculture edn: Tunis; 1979.

22. Stenhagen $E$, Abrahamson S, McLafferty FW. Registry of mass spectral data Wiley, New York edn; 1974

23. Masada Y. Analysis of essential oils by gas chromatography and mass spectrometry. 1976.

24. Jennings W, Shibamoto T. Qualitative analysis of flavour and fragrance volatile by capillary GC. In.: New York: Academic Press. 1980;

25. Swigar A, Silverstein R. Monoterpenes. Milwaukee, Wisconsin, USA: Aldrich Chemical Company. Inc: 1981. p. 130

26. Davies N. Gas chromatographic retention indices of monoterpenes and sesquiterpenes on methyl silicon and Carbowax 20M phases. J Chromatogr A. 1990;503:1-24.

27. Adams R. Identification of essential oil components by gas chromatography-mass spectroscopy. Allured, Carol Stream. edn. 1995;

28. Bero J, Hannaert V, Chataigne G, Herent MF, Quetin-Leclercq J. In vitro antitrypanosomal and antileishmanial activity of plants used in Benin in traditional medicine and bio-guided fractionation of the most active extract J ethnopharmacol. 2011;137:998-1002.

29. Bero J, Ganfon H, Jonville MC, Frederich M, Gbaguidi F, DeMol P, Moudachirou M, Quetin-Leclercq J. In vitro antiplasmodial activity of plants used in Benin in traditional medicine to treat malaria. J ethnopharmacol. 2009:122:439-44.

30. Weniger B, Robledo S, Arango GJ, Deharo E, Aragon R, Munoz V, Callapa J, Lobstein A, Anton R. Antiprotozoal activities of Colombian plants. J ethnopharmacol. 2001;78:193-200.

31. Camacho M, Forero ME, Fajardo C, Nino A, Morales P, Campos H. Leishmania amazonensis infection may affect the ability of the host macrophage to be activated by altering their outward potassium currents. Exp Parasitol. 2008;120:50-6.

32. Monzote L, Piñón A, Setzer WN. Antileishmanial potential of tropical rainforest plant extracts. Medicines. 2014;1:32-55.

33. Yari M, Masoudi S, Rustaiyan A. Essential Oil of Haplophyllum tuberculatum (Forssk.) A. Juss. Grown Wild in Iran. J Essent Oil Res. 2000;12:69-70.

34. Al Yousuf MH, Bashir AK, Veres K, Dobos Á, Nagy G, Máthé I, Blunden G, Vera JR. Essential oil of Haplophyllum tuberculatum (Forssk.) A. Juss. from the United Arab Emirates. J Essent Oil Res. 2005;17:519-21.

35. Misharina TA, Polshkov AN. Antioxidant Properties of Essential Oils: Autoxidation of Essential Oils from Laurel and Fennel and of Their Mixtures with Essential Oil from Coriander. Appl Biochem Microt. 2005:41:610-8.

36. Misharina TA, Polshkov AN, Ruchkina EL, Medvedeva IB. Changes in the Composition of the Essential Oil of Marjoram during Storage. Appl Biochem Micro+. 2003;39:311-6.

37. Hussain Al, Anwar F, Sherazi STH, Przybylski R. Chemical composition, antioxidant and antimicrobial activities of basil (Ocimum basilicum) essential oils depends on seasonal variations. Food chem. 2008;108:986-95.

38. Kpadonou Kpoviessi BG, Kpoviessi SD, Yayi Ladekan E, Gbaguidi F, Frederich M, Moudachirou M, Quetin-Leclerca J, Accrombessi GC, Bero J. In vitro antitrypanosomal and antiplasmodial activities of crude extracts and essential oils of Ocimum gratissimum Linn from Benin and influence of vegetative stage. J ethnopharmacol. 2014;155:1417-23.

39. do Socorro SRMS, Mendonca-Filho RR, Bizzo HR, de Almeida Rodrigues I, Soares RM, Souto-Padron T, Alviano CS, Lopes AH. Antileishmanial activity of a linalool-rich essential oil from Croton cajucara. Antimicrob Agents Chemother. 2003:47:1895-901.

40. Mikus J, Harkenthal M, Steverding D, Reichling J. In vitro effect of essential oils and isolated mono- and sesquiterpenes on Leishmania major and Trypanosoma brucei. Planta Med. 2000;66:366-8.

41. SLd S, Figueiredo PM, Yano T. Cytotoxic evaluation of essential oil from Zanthoxylum rhoifolium Lam. leaves. Acta Amaz. 2007;37:281-6.

42. Usta J, Kreydiyyeh S, Knio K, Barnabe P, Bou-Moughlabay Y, Dagher S. Linalool decreases HepG2 viability by inhibiting mitochondrial complexes I 
and II, increasing reactive oxygen species and decreasing ATP and GSH levels. Chem Biol Interact. 2009;180:39-46.

43. Ravizza R, Gariboldi MB, Molteni R, Monti E. Linalool, a plant-derived monoterpene alcohol, reverses doxorubicin resistance in human breast adenocarcinoma cells. Oncol Rep. 2008;20:625.

44. Gu Y, Ting Z, Qiu X, Zhang X, Gan X, Fang Y, Xu X, Xu R. Linalool preferentially induces robust apoptosis of a variety of leukemia cells via upregulating p53 and cyclin-dependent kinase inhibitors. Toxicology. 2010; 268:19-24.

45. Ji J, Zhang L, Wu Y-Y, Zhu X-Y, Lv S-Q, Sun X-Z. Induction of apoptosis by $\mathrm{d}$ limonene is mediated by a caspase-dependent mitochondrial death pathway in human leukemia cells. Leuk Lymphoma. 2006;47:2617-24.

46. Chidambara Murthy KN, Jayaprakasha G, Mantur SM, Patil BS. Citrus monoterpenes: potential source of phytochemicals for cancer prevention. In: Emerging Trends in Dietary Components for Preventing and Combating Disease. edn.: ACS Publications; 2012: 545-558.

47. Fraternale D, Ricci D, Calcabrini C, Guescini M, Martinelli C, Sestili P. Cytotoxic activity of essential oils of aerial parts and ripe fruits of Echinophora spinosa (Apiaceae). Nat Prod Commun. 2013;8:1645-9.

48. Crowell PL, Ayoubi AS, Burke YD. Antitumorigenic effects of limonene and perillyl alcohol against pancreatic and breast cancer. In: American Institute for Cancer Research, editors. Dietary Phytochemicals in Cancer Prevention and Treatment. edn. Boston: Springer; 1996. p. 131-6. https://link.springer. com/chapter/10.1007/978-1-4613-0399-2_10.

49. Lampronti I, Saab AM, Gambari R. Antiproliferative activity of essential oils derived from plants belonging to the Magnoliophyta division. Int J Oncol. 2006;29:989-96.

50. Ferraz RP, Bomfim DS, Carvalho NC, Soares MB, da Silva TB, Machado WJ Prata APN, Costa EV, Moraes VRS, Nogueira PCL. Cytotoxic effect of leaf essential oil of Lippia gracilis Schauer (Verbenaceae). Phytomedicine. 2013; 20:615-21.

51. Kpoviessi S, Bero J, Agbani P, Gbaguidi F, Kpadonou-Kpoviessi B, Sinsin B, Accrombessi G, Frederich M, Moudachirou M, Quetin-Leclercq J. Chemical composition, cytotoxicity and in vitro antitrypanosomal and antiplasmodial activity of the essential oils of four Cymbopogon species from Benin. J ethnopharmacol. 2014;151:652-9.

52. Greay SJ, Ireland DJ, Kissick HT, Levy A, Beilharz MW, Riley TV, Carson CF. Induction of necrosis and cell cycle arrest in murine cancer cell lines by Melaleuca alternifolia (tea tree) oil and terpinen-4-ol. Cancer Chemother Pharmacol. 2010;65:877-88

53. Varamini P, Doroudchi M, Mohagheghzadeh A, Soltani M, Ghaderi A. Cytotoxic Evaluation of Four Haplophyllum Species with Various Tumor Cell Lines. Pharm Biol. 2007;45:299-302.

54. Kuete V, Wiench B, Alsaid MS, Alyahya MA, Fankam AG, Shahat AA, Efferth T. Cytotoxicity, mode of action and antibacterial activities of selected Saudi Arabian medicinal plants. BMC Complement Altern Med. 2013;13:354.

55. Sheriha GM, Abouamer K, Elshtaiwi BZ, Ashour AS, Abed FA, Alhallaq HH. Quinoline alkaloids and cytotoxic lignans from Haplophyllum tuberculatum. Phytochemistry. 1987;26:3339-41.

56. Fumarola L, Spinelli R, Brandonisio O. In vitro assays for evaluation of drug activity against Leishmania spp. Res Microbiol. 2004;155:224-30.

\section{Submit your next manuscript to BioMed Central and we will help you at every step:}

- We accept pre-submission inquiries

- Our selector tool helps you to find the most relevant journal

- We provide round the clock customer support

- Convenient online submission

- Thorough peer review

- Inclusion in PubMed and all major indexing services

- Maximum visibility for your research

Submit your manuscript at www.biomedcentral.com/submit

) Biomed Central 